Original research article

\title{
Lived experience of outpatients with Parkinson's disease: an interpretative phenomenological analysis
}

\author{
Martina Tomagová *, Ivana Bóriková, Martina Lepiešová, Jana Nemcová, Ivan Farský, \\ Mária Zanovitová \\ Comenius University in Bratislava, Jessenius Faculty of Medicine in Martin, Department of Nursing, Martin, Slovak Republic
}

\begin{abstract}
Introduction: The chronic, degenerative and progressive character of Parkinson's disease (PD) is reflected in the living experience of patients - and it also has an impact on their dignity.

Aim: The aim of the study was to increase the understanding of the lived experience of outpatients with PD and its impact on their dignity. Methods: The study design is explorative using interpretative phenomenological analysis (IPA). Semi-structured interviews were held with 11 participants with PD between February-May 2018. Interviews were conducted as individual face-to-face interviews, in privacy with no involvement of family members according to the interview protocol. Data analysis was performed according to IPA process using the ATLAS.ti 8.0 program.

Results: Our study identified five themes that reflect the lived experience of outpatients with PD: Me and my Parkinson's: losses, acceptance and coping; The Need to Remain Self-sufficient versus the Fear of Dependence; How Do Others See Me: Scorn versus Acceptance; Lack of Information versus the Need to Be Informed; Lack of Respect versus the Accommodating Approach of Healthcare Professionals. We discovered their impact on dignity, especially in the areas concerning autonomy, self-esteem, self-worth, identity, respect, and other people's appreciation.

Conclusions: Patients with PD are confronted with many serious changes on a daily basis, which significantly influence their dignity. This fact must be known and respected by health care professionals when providing patient-oriented care.
\end{abstract}

Keywords: Dignity; Health care; Interpretative Phenomenological Analysis; Lived experience; Parkinson's disease

\section{Introduction}

Parkinson's disease (PD) is the second most common neurodegenerative condition in the world, with evolving layers of complexity (Kalia and Lang, 2015). The chronic and progressive character of $\mathrm{PD}$, accompanied by typical motor and non-motor symptoms, their instability and volatility seriously impair the physical and mental health of patients (Valcarenghi et al., 2018; Vescovelli et al., 2018). The lived experience of patients with PD is significantly influenced by the complexity of clinical manifestations of the disease, gradual decline in self-care, increasing disability, and exacting therapy (Bonner et al., 2020; Eatough and Shaw, 2019; Shapira et al., 2017; Smith and Shaw, 2017). Lived experience represents how the person reflects the significance of what has happened and how he or she engages in trying to make sense of it (Smith et al., 2009). Qualitative research studies (Haahr et al., 2017; Gibson and Kierans, 2017; Kang and Ellis-Hill, 2015; Soleimani et al., 2014) describe the wide spectrum of PD patients' lived experi- ences and its impact on their dignity. These authors also point out other possibilities for studying these experiences. Dignity is a subjective concept, and how it is perceived and received in practice is individual.

Patients with PD notice that the physical and mental changes affect their self-esteem, as well as how they are perceived by others. Patients can feel humiliated and less confident when judged by others. Loss of identity and dignity altered family relationships, and brought a sense of being worthless (Hammarlund et al., 2018).

The importance of healthcare professionals respecting this concept is shown through the provision of individualized, person-centered and holistic healthcare (Tranvåg et al., 2016; Žiaková et al., 2020). Emphasizing the importance of maintaining a patient's dignity should be a central component of healthcare (Jacobs et al., 2001). Baillie (2009) suggest that this is a complex and multi-dimensional concept. The supporting and strengthening of it, as well as the threatening or violation of it, are sensitively perceived by every single patient. An overview of the dynamics of this concept is crucial for understand-

\footnotetext{
* Corresponding author: Martina Tomagová, Comenius University in Bratislava, Jessenius Faculty of Medicine in Martin, Department of Nursing, Malá Hora 5, 03601 Martin, Slovak Republic; e-mail: martina.tomagova@uniba.sk http://doi.org/10.32725/kont.2021.049 
ing what patients perceive dignity to be, and how they strive to maintain their personal dignity and face progressive changes and losses. Proactive and continuous care aimed at maintaining a patient's dignity throughout the trajectory of the disease can be provided on this basis (van Gennip et al., 2015).

The aim of the study was to increase the understanding of the lived experience of outpatients with PD and its impact on their dignity.

\section{Materials and methods}

This qualitative study design is explorative with a phenomenological approach, based on interpretative phenomenological analysis (IPA) which strives to understand an individual's lived experience. The IPA is a flexible method based on phenomenology, hermeneutics and ideography. It is focused on a detailed examination of human lived experience, characterized by deep analysis of a small homogenous sample. It is understood as a complex concept, and emphasis is placed on what happens when everyday experiences acquire a special meaning for an individual; this usually occurs when something important takes place in an individual's life (Pietkiewicz and Smith, 2014; Smith and Osborn, 2015; Smith et al., 2009).

Participants were purposively recruited from the outpatient clinic for the treatment of people with PD at a university hospital in Central Slovakia. Twenty-eight participants were contacted by mail to be part of the study. Based on the inclusion criteria, 11 participants were included in the study ( 7 women and 4 men with an average age of 67 years). The inclusion criteria was: PD diagnosed, preserved speech and mobility, intact cognitive functions, absence of depression (depression can lead to a reduction in the patient's ability to cooperate during the interview), willingness to participate in the study, and a signed informed consent. The characteristics of the participants are shown in Table 1.

Table 1. Characteristics of interviewed participants

\begin{tabular}{|c|c|c|c|c|c|}
\hline Participant* & Age & Education & Marital status & Employment & Duration of PD (years) \\
\hline Agatha & 71 & Secondary & Widower & Old-age pensioner & 4 \\
\hline Donna & 63 & University & Married & Old-age pensioner & 10 \\
\hline Henry & 63 & Secondary & Married & Old-age pensioner & 20 \\
\hline Jake & 66 & Secondary & Married & Old-age pensioner & 13 \\
\hline Clara & 47 & Secondary & Married & Disability retirement & 8 \\
\hline Sue & 72 & University & Widower & Old-age pensioner & 10 \\
\hline Oscar & 74 & Secondary & Married & Old-age pensioner & 7 \\
\hline Adam & 66 & University & Divorced & Librarian & 7 \\
\hline Erika & 76 & University & Married & Old-age pensioner & 17 \\
\hline Glenda & 73 & Secondary & Married & Old-age pensioner & 8 \\
\hline Hilda & 65 & Secondary & Married & Old-age pensioner & 12 \\
\hline
\end{tabular}

Data collection was carried out in the form of semi-structured interviews that focused on the issue of dignity, between February-May 2018. Interviews were conducted as individual face-to-face interviews, in privacy, with no involvement of family members and according to the interview protocol. The researchers were not involved in the care of the participants. Interviews were conducted by the first (MT), second (IB), and third researcher (ML). After the introductory rapport phase, participants were asked questions related to dignity. The main research questions were: Can you tell me what dignity mean for you? Can you tell me how PD affects your sense of dignity? Can you tell me how treatment and care influence your sense of dignity?

The interviews were audio-recorded, and the researcher took field notes on the environment, the length of the interview (it varied from 33 to 100 minutes), the behavior of participants, and the researcher's own reflection on his/her role during the interview. Transcripts were not returned to participants. Data saturation was discussed by researchers.

Before the interview, each participant was acquainted with the objectives and content of the study. They were informed about anonymity and confidentiality, voluntary participation, and the possibility of withdrawal from the study without it affecting the care they receive. In the write up of our analysis, we have used the pseudonyms of participants. The study was approved by the university Ethics Committee, and was performed in accordance with the criteria of the Helsinki Declaration of 1964 (as revised in 2013).

Data analysis was conducted in several consecutive steps according to IPA (Reading and rereading, Initial noting, Developing emergent themes, Searching for connections across emergent themes, Looking for patterns across cases) (Pietkiewicz and Smith 2014; Smith et al., 2009) using the ATLAS. ti 8.0 program. The first step included several thorough readings of the interview transcript, taking notes, and writing commentaries about the content of the interview and the use of language by specific participants (description). The themes that represented the participant's unique experience were subsequently identified and described (semantic analysis). These themes were then grouped according to concept similarities, and the results of the analyses were addressed, discussed and recorded.

The transcript of each interview was repeatedly read, coded by three researchers with the assistance of the computer software program ATLAS.ti 8.0, and analysed by two researchers independently (triangulation of research). Their findings were synthetized and discussed, the similarities and differences were identified, and the final form of the analysis of the lived experience with an impact on his/her dignity was created based on the authors consensus. This analysis was then checked by 
one researcher (peer debriefing), enhancing the credibility and rigor of the study as an essential requirement for qualitative studies (Soleimani et al., 2014).

\section{Results}

Based on the analysis of interviews with PD participants, we identified and described the following mutually linked themes related to lived experience (Diagram 1):
- Me and my Parkinson's: losses, acceptance and coping;

- The need to remain self-sufficient versus the fear of dependence;

- How do others see me: scorn versus acceptance;

- Lack of information versus the need to be informed;

- Lack of respect versus the accommodating approach of healthcare professionals.

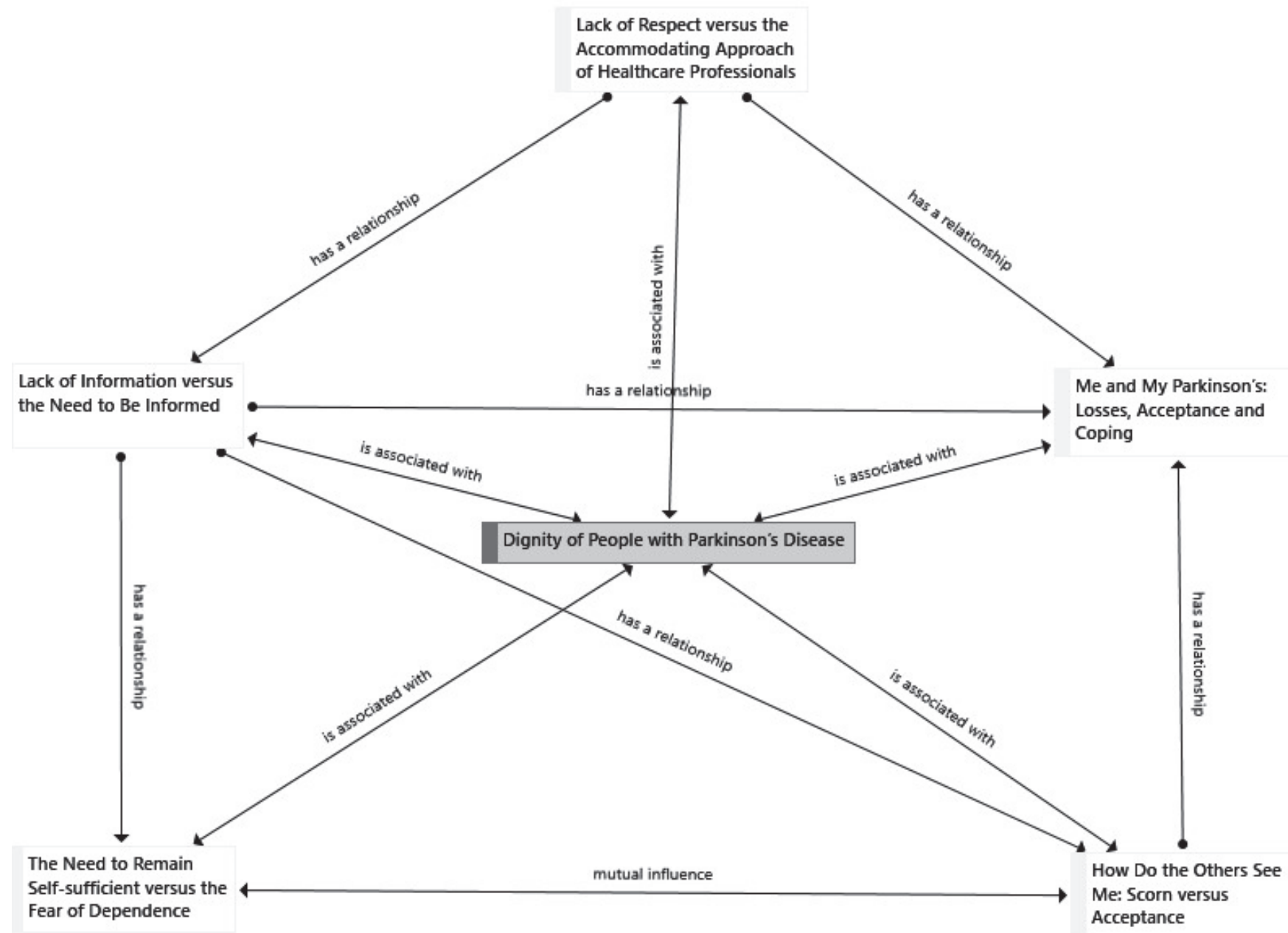

Diagram 1. Themes identified in connection to participants' dignity and their relationships

\section{Me and my Parkinson's: losses, acceptance and coping}

Accepting the disease, coping with it, and managing everyday problems and limitations are present in the lived experience of PD participants. Glenda perceived the diagnosis as a "shock and surprise": "Oh My God, why?!" Clare's "world fell apart", she perceived the diagnosis as "God's retribution"; and questioned her own value and the meaning of life: "Why am I in this world?" Donna recalls: "Well, it affected my dignity." Hilda perceived her disease as an injustice: "Such a thing shouldn't happen to decent people!" After confronting the diagnosis, the participants emphasized that "disease must be accepted somehow; otherwise you will groan your heart out" (Hilda). Sue identified with her disease as "my Mr. Parkinson". She understands it as a challenge, and emphasizes the necessity to try to live "in dignity as a human being despite the PD".
Donna is capable of talking about her disease with humor. She is bold and proposes solutions: "Doctor, why don't we make some changes? ... Some experiment?" These expressions point to a positive attitude toward the disease that could be explained as acceptance.

However, people with PD also think about the limitations and losses related to the disease, which limit their autonomy. "I had to give up the things that I loved ... driving for example" (Erika). "I don't dare take longer trips" (Adam). Limitations are reflected in impaired personal identity. "I'm not who I used to be because of the disease" (Hilda). Others, such as Clara, experienced feelings of shame: "I can't afford to buy my son what he needs ... I'm ashamed because of it"; and in reduced self-confidence and social status: "Unfortunately, the disease is winning, and I have had to resign from my managerial post" (Jake). 
Participants presented various methods of coping. These help them to maintain their autonomy and to see prospects for the future, while simultaneously acknowledging the progressive nature of PD.

Sue characterizes herself as "a fighter". She has some recommendations in relation to how to maintain one's dignity: "Don't whine, try to help yourself actively." As opposed to this proactive approach, Erika manages her disease in a more passive manner: "I'll sit down and wait in peace."

Changes in health due to the various activities that people with PD carry out to "fight" their disease are connected with experiencing hope, "I'm undergoing therapy for incontinence and I hope that it will be resolved" (Adam), or hopelessness: "It broke $m e "$ (Hilda). Oscar trivializes his disease and indicates that he is a passive recipient of treatment: "I do everything I'm told to do."

\section{The need to remain self-sufficient versus the fear of dependence}

People with PD expressed a decline in motor control and self-sufficiency in performing daily activities. Agatha feels "terrible" because "the disease controls me and not me the disease... I do not control the situation". Adam fears that he will not be able to find the toilet: "I'll get stuck and I can't function as I want to." Sue has problems with activities that require fine motor skills, She cannot: "Handle small coins, bags of food, buttoning buttons."

People with PD have a need to be self-sufficient and useful to their families, and not to be a burden. Clara states: "I' $m$ happy when I am able to fulfil my role as a mother." The progression of the disease brings the growing fear of losing autonomy and dignity, and of increased dependence on others. Erika says: "I have to do it on my own ... If someone starts to help me, I just stop being self-sufficient ... Dependent individual can't do anything freely ... I will stop existing." Dignity and the meaning of life are also connected with social activities, but progressive decline up to the loss of motor functions limits this participation. Erika gave up her vacations and theater: "... one can feel that strange gaze ...". Hilda reduced "her church visits". Participants consider possibilities of self-fulfillment and creative activities to be important for their dignity. Sue is happy when she performs "special exercises using vibrating rings, tai chi, breathing exercises, and takes trips to the mountains".

Planning activities sometimes helps. "I try various tricks for walking" (Donna). "I always worry whether I will handle walking up the stairs or through the narrow spaces if I don't expect them..." (Hilda). In terms of future life perspectives and support of personal identity, people with PD prepare for the deterioration of their condition. "The disease gives me some time to get ready for certain situations ... I adjusted my house to be 'barrier free'..." (Jake). "I'd consider a social facility if my health deteriorates, it's a difficult dilemma" (Adam).

\section{How do others see me: scorn versus acceptance}

How others perceive and evaluate people with PD is a significant social factor that has an impact on their identity. Participants describe ridicule, insults, misunderstandings, and unpleasant pity. "I met people who were scolding me, laughing at $m e$ " (Jake). There is also excessive and unreasonable assistance from the community, which threatens their dignity. The negative assessment of their appearance also has a negative impact on their dignity. "People tell me that I don't look good, I'm haggard... they say 'She's drunk!'” (Clara). "You can feel those looks; they're almost poisonous, condemning" (Henry).

Such negative views and opinions of others affect participants' self-image and contribute to the development and deepening of their social isolation. "What others thought of me was unpleasant: if he has problems handling himself, why doesn't he stay at home?!" (Jake). The public's views and prejudices toward people with PD threatens their dignity, which contributes to further limitations in social activities. "The community considered me as an individual who couldn't fully carry out activities ... as stupid, crazy" (Henry). Participants consider the compassion, pity, and excessive unsolicited assistance to be an unpleasant and undignified response to their disability. Henry says: "I hate compassion, I say: That's enough, friends and family! I have Parkinson's, but my head still works fine." On the contrary, people with PD perceive acceptance and solidarity as strengthening their dignity, because they have social contact with someone who understands them and shares their burden. Participants consider their families to be a significant source of support. "My family gives me strength" (Hilda). On the other hand, they don't like it when family consider them to be incapable and prevent them from carrying out ordinary activities - as a result of which they lose part of their identity. "I'm not allowed to do anything at home anymore, that's the worst for me" (Henry).

Support groups are another source of social support. These help to strengthen dignity because they create an environment of equality. "You meet people who don't feel superior to you" (Agatha). They also allow patients to replace social contacts that have been reduced due to various limitations; "I can experience the feeling of being useful, being important" (Henry). On the other hand, even within this group, patients can be disappointed in interpersonal relations. "I expected support, acceptance of my opinions, suggestions for activities, but I felt misunderstood, underappreciated" (Clara).

\section{Lack of information versus the need to be informed}

The participants declared a lack and unavailability of information. They expect specific information to enhance their self-management of PD, and to verify whether their course of actions is correct or not. "It's very difficult to get information ... I'm not always convinced that I'm doing something good to improve my health, but I don't have anybody to talk to about it" (Sue). Participants are not clear about who should be the source of information. "I don't know whether to expect advice from the staff or from some organization?" (Jake). Glenda is critical: "We had no idea that there were clubs for PD patients. Nobody told us!"

Participants perceive the failure of healthcare professionals to provide information as a sign of their lack of time, or they justify it. "Healthcare professionals have other things to do, they save patients" (Jake). Patients emphasize the significance of the general public being informed about PD. "The public lack information about this disease, and as a result, they're scared and look at people with disrespect" (Sue). On the other hand, Henry talks about the necessity to inform close relatives: "Families must be clearly told: Don't pick on them, don't limit them!"

According to the patients, lack of information may contribute to insufficient acceptance of the disease and the inability to manage themselves. Sue experienced her neurologist's failure in delivering bad news when he first confirmed the diagnosis of PD: "He prescribed the medications ... and when I asked: What can I do as a patient? ... He said: With this diagnosis?! Nothing (?!)." She experienced a degrading style of communication, reflecting the dominance of paternalism and leading to a violation of her dignity, which hindered the development of hope. "Basically, the doctor treated me as if I wasn't able to count to ten!" Sue considers the exchange of information and experience to be crucial for preserving dignity: "My dignity is promoted by constantly looking for information and new opportunities." 


\section{Lack of respect versus the accommodating approach of healthcare professionals}

The approach of healthcare professionals has a significant impact on the dignity of people with PD. This social aspect of dignity is expressed through the rate in which they are shown respect. Hilda states: "My status has not been respected by nurses ..., patients are not just numbers or codes." Considering she was formerly a nurse, she considers this to be a distinct violation of her dignity. Oscar considers it undignified when a healthcare professional acts "like a policeman". Erika sensitively perceives misunderstandings through non-verbal communication: "She looks at me and doesn't say anything, but I can tell what she's thinking from the expression on her face." Such an approach leads to helplessness, loss of one's sense of worth, and eventually the degradation of identity and dignity.

Disrespecting the ability of people with PD to make decisions about and for themselves also has a negative impact on their dignity. Hilda remembers how a nurse decided what she should wear on a cold day when she was being transported for examination: "Do you know what would happen if we listened to the patients? We know how to dress you!" Such manifestations of paternalism devalue the relationship between the healthcare provider and the patient. The dignity of people with PD is also impaired by the stereotypical approach of disrespecting the patient's individuality. Agatha recalled an orthopedic surgeon who failed to reflect on the fact that she suffers from PD: "What do you want? You should walk 8 kilometers every day ... I can barely take a few steps?!"

Participants also consider the conditions in healthcare facilities to be undignified. They don't have any privacy during the rounds. "Everybody can hear what they're saying about me" (Jake). Sue points to overcrowded waiting rooms and long waiting times: "We sit here in an undignified manner, we wait there for hours. I even wanted to take a mat to lie on if I didn't feel well." On the contrary, they consider a personal and welcoming approach of staff to be supportive of dignity. "The staff's communication is pleasant, their approach is responsible, they don't turn patients into objects and they approach them with respect like humans, living beings" (Sue). Participants consider patience and time to be important support factors. These strengthen respect because they cannot always perform activities on command. "We need some time before we can move ... I'm aware of the fact that the staff are under time constraints, the emphasis is on written documents - which is also necessary, but then they don't have time for patients" (Hilda).

\section{Discussion}

PD is a progressive disease, so those who suffer from it face changes and loss, some of which directly affect their sense of dignity. Participants experience their dignity being impaired by the transition from an autonomous individual to a dependent individual. They experience a wide range of emotional reactions at various stages of PD, particularly during the diagnostic process, when patients are under pressure similar to that described by Nazzal and Khalil (2017). Patients with chronic disease travel linearly through a series of stages or phases, starting with shock and denial, followed by anger, bargaining and depression, and finally reaching a stage of acceptance (Eccles et al., 2011). This has also been seen in our own results in the theme Me and my Parkinson's. Accepting the disease is the fundamental condition for adapting to chronic disease (Ambrosio et al., 2015). This affects psycho-emotional well-being and a patient's sense of self (Simpson et al., 2013). As de- scribed in our sample, acceptance is achieved by a combination of many factors, which, together with perceived losses and experienced limitations, affect coping. In some descriptions of our participants, the attributes of self-management, integrity and active adjustment to a disease were also present. Ishii and Okuyama (2017) state that unpredictable and difficult to control PD symptoms have a negative impact on the management of everyday activities. This causes frustration, helplessness, and increased awareness of a lack of physical and cognitive control. Our participants stated that their dignity is also threatened by the unpredictable and uncontrollable symptoms of PD they experience when they try to meet their needs.

Patients whose personal dignity is destroyed frequently feel that they have no value anymore and that their life has no meaning (van Gennip et al., 2013). According to our participants it is undignified to ask for assistance with basic activities, and the reliance on others may lead to shame, loss of self-confidence, self-respect, feelings of worthlessness and personal failure. Participants use various compensatory strategies to maintain their independence, such as adapting to various situations, looking for practical solutions, foreseeing and planning activities, using aids, and accepting assistance from families. Hammarlund et al. (2018) note that the inability to take care of oneself and one's family, especially in the sense of traditional roles, is extremely unpleasant - particularly for women. One of our participants, Clara, expressed that she had this experience.

For our participants to strengthen their personal dignity, it is important they do something that makes sense (Sue). Hammarlund et al. (2018) and Perepezko et al. (2019) emphasize that enjoying even small everyday matters brings feelings of happiness and prevents isolation (which otherwise could lead to depression).

Due to visible PD symptoms, our participants experience a wide spectrum of negative reactions from the public, which leads to social isolation, embarrassment, feelings of inferiority, loss of identity, and limitations to social activities. Simultaneously, they are also confronted with stigma from external sources (Maffoni et al., 2017).

Social support contributes to social inclusion, the possibility to work, to experience happiness, to maintain social status and identity. Family and friends are a significant source of emotional support, social interaction, and assistance for our participants. Kang and Ellis-Hill (2015) state that spending time with friends and family helps patients to experience the feeling of solidarity. It maintains their own value and supports their dignity. However, family support should not be a reaction to perceiving the patient as disabled, or hinder his or her striving for independence (Nazzal and Khalil, 2017). One of our participants, Henry, also mentioned the experience of over-care from his family, which hindered his independence.

Support groups for participants (Agatha, Henry) have a predominantly positive impact on their dignity; they help to increase self-respect and participation in social activities. Hellqvist et al. (2018) stress that membership in a group allows patients to achieve a new identity and sense of self. Support groups have become a common and effective form of help, developing a sense of belonging, sharing experiences, emotional support, communication and meeting other PD patients (Bush et al., 2018; Sheehy et al., 2017).

Communication is a major component of care: it is obvious that people with PD, particularly at the beginning of the disease, lack basic information regarding symptom expression, disease progression, and ways to overcome common disease-related problems and difficulties (Tsiouris et al., 2017). In 
our study, participants reported that they have not been sufficiently informed (for example, about the possibilities of rehabilitation). This is something that was also noted in a study by the authors Tod et al. (2016). Participants expect healthcare professionals to treat them with respect, and as people with a unique identity and dignity. The patient's dignity should not be a cliché in patient care. Our participants perceived dignified care to include respecting a patient's personality, maintaining their independence and autonomy, respecting their privacy, creating suitable conditions for care, providing information, and a comprehensive holistic approach. Matiti (2015), Eatough and Shaw (2019) present dignity through categories such as respecting privacy, confidentiality, information, the possibility to make one's own decisions and to be involved in care, to maintain independence, decency, control over one's life, and respect in nurse-patient communication. Nurses should not forget that people with PD want to be acknowledged not only as patients, but also as people who in the past fulfilled their personal and professional roles. The stereotypical perception of people with PD as individuals with serious symptoms can result in a loss of self-respect, feelings of worthlessness, and lowered personal identity and dignity (Hammarlund et al., 2018).

The perspectives of people and healthcare professionals related to PD symptomatology, its diagnostics, monitoring of the condition, and care management, frequently differ. Potentially this can result in misunderstandings, the inability to understand patient's problems, and inadequate or insufficient treatment (Stocchi et al., 2014). This may lead to ineffective and fragmented care (Soundy et al., 2014), with a lack of respect for the person's individuality and dignity. Van Gennip et al. (2013) stress that in cases where patients suffer from serious diseases, the study of dignity deserves more attention. Nurses should get to know and try to understand the expectations of people with $\mathrm{PD}$, reinforce holistic and patient-centred care, and contribute to creating a sense of their dignity (Lin et al., 2013). When confronted with life-limiting illness, patients should always receive patient-centered care (Fine, 2010).

\section{Limitations}

The study has several limitations. The interviews had different duration lengths, as they were adapted to the participants' health condition and willingness to cooperate. The interpretation of the lived experience of people with PD may be influenced by the personal and professional views of the authors as nurses. This issue was carefully reflected upon during the research. We participated in an ongoing open dialogue in which our diverse pre-understandings were challenged. The final interpretation of the cases and cross-case analysis were based on the authors' consensus, whereby the authors tried to increase the rigor as well as the credibility of the study.

\section{Conclusions}

The study presents the individual lived experiences of people with PD and the impact of the disease on their personal dignity, especially in the areas of disease acceptance, and the need to remain independent, to be respected by nurses, to be accepted by other people, and to be sufficiently informed. The study provides evidence of factors affecting the dignity of people with $\mathrm{PD}$, which is the basis for providing adequate and proactive care. By understanding individual experience, it is possible to carry out concrete interventions promoting their dignity.

The findings of this study extend knowledge about the sense of dignity experienced by people with PD in the context of health care. There is still room for further research to identify how people with PD perceive dignity in the context of healthcare.

\section{Ethical aspects and conflict of interests}

The authors have no conflict of interests to declare.

\section{Acknowledgements}

This research is supported by VEGA grant 1/0090/17: Dignity of patients with neurological disease in the context of healthcare: interpretative phenomenological approach.

\section{Životná skúsenost' ambulantných pacientov s Parkinsonovou chorobou: interpretatívno fenomenologická analýza}

Súhrn

Úvod: Chronický, degeneratívny a progresívny charakter Parkinsonovej choroby (PD) sa odráža v životnej skúsenosti pacientov, pretože má vplyv aj na ich dôstojnost́.

Ciel': Ciel'om štúdie bolo zvýšit' porozumenie životnej skúsenosti pacientov s PD v ambulantnej starostlivosti a jej vplyvu na ich dôstojnost'.

Metódy: Dizajn štúdie je exploratívny s využitím interpretatívno fenomenologickej analýzy (IPA). Semištruktúrované rozhovory sa uskutočnili s 11 participantmi s PD v období od februára do mája 2018. Rozhovory sa uskutočnili ako individuálne osobné rozhovory, v súkromí bez účasti rodinných príslušníkov podl'a protokolu rozhovoru. Analýza údajov sa uskutočnila podl'a procesu IPA s použitím programu ATLAS.ti 8.0.

Výsledky: Naša štúdia identifikovala pät' tém, ktoré odrážajú životnú skúsenost' pacientov s PD v ambulantnej starostlivosti: Ja a môj Parkinson: straty, akceptácia a koping; Potreba zostat' sebestačný verzus obava zo závislosti; Ako ma vidia iní: opovrhnutie verzus prijatie; Nedostatok informácií verzus potreba byt' informovaný; Nedostatok rešpektu verzus ústretový prístup zdravotníckych pracovníkov. Identifikovali sme ich vplyv na dôstojnost́ pacientov, najmä v oblastiach týkajúcich sa autonómie, sebaúcty, vlastnej hodnoty, identity, rešpektu a uznania druhými l'udí.

Záver: Pacienti s PD sú denne konfrontovaní s mnohými závažnými zmenami, ktoré výrazne ovplyvňujú ich dôstojnost́. Túto skutočnost' musia zdravotnícki pracovníci poznat' a rešpektovat' pri poskytovaní starostlivosti orientovanej na pacienta.

Kl'účové slová: dôstojnost'; interpretatívno fenomenologická analýza; Parkinsonova choroba; zdravotná starostlivost'; životná skúsenost' 


\section{References}

1. Ambrosio L, García JMS, Fernández MR, Bravo SA, De Cerio Ayesa SD, Caparrós N, et al. (2015). Living with chronic illness in adults: a concept analysis. J Clin Nurs 24(17-18): 23572367. DOI: $10.1111 /$ jocn.12827.

2. Baillie L (2009). Patient dignity in an acute hospital setting: a case study. Int J Nurs Stud 46(1): 23-37. DOI: 10.1016/j. ijnurstu.2008.08.003.

3. Bonner N, Bozzi S, Morgan L, Mason B, Peterschmitt MJ, Fischer TZ, et al. (2020). Patients' experiences of Parkinson's disease: a qualitative study in glucocerebrosidase and idiopathic Parkinson's disease. J Patient Rep Outcomes 4(1): 65-79. DOI: 10.1186/s41687-020-00230-9.

4. Bush EJ, Singh RL, Hidecker MC, Carrico CP (2018). Parkinson's disease support groups in Rural America: barriers, resources, and opportunities. TQR 23(6): 1381-1400. DOI: $10.46743 / 2160-3715 / 2018.3312$.

5. Eatough V, Shaw K (2019). "It's like having an evil twin": an interpretative phenomenological analysis of the lifeworld of a person with Parkinson's disease. J Res Nurs 24(1-2): 49-58. DOI: $10.1177 / 1744987118821396$.

6. Eccles FJR, Murray C, Simpson J (2011). Perceptions of cause and control in people with Parkinson's disease. Disabil Rehabil 33(15-16):1409-20. DOI: 10.3109/09638288.2010.533241.

7. Fine RL (2010). Keeping the patient at the center of patient and family-centered care. J Pain Symptom Manage 40(4): 621-625. DOI: 10.1016/j.jpainsymman.2010.06.008.

8. Haahr A, Brincks J, Sørensen D (2017). Coping with Parkinson's disease in everyday life: a systematic review protocol. JBI Database System Rev Implement Rep 15(5): 1288-1297. DOI: 10.11124/JBISRIR-2016-002989.

9. Hammarlund CS, Westergren A, Åström I, Edberg AK, Hagell P (2018). The impact of living with Parkinson's disease: balancing within a web of needs and demands. Parkinsons Dis 29(7): 1-8. DOI: $10.1155 / 2018 / 4598651$.

10. Hellqvist C, Dizdar N, Hagell P, Berterö C, Sund-Levander M (2018). Improving self-management for persons with Parkinson's disease through education focusing on management of daily life: patients' and relatives' experience of the Swedish National Parkinson School. J Clin Nurs 27(19-20): 3719-3728. DOI: 10.1111 /jocn. 14522.

11. Gibson G, Kierans C (2017). Ageing, masculinity and Parkinson's disease: embodied perspectives. Sociol Health Illn 39(4): 532-546. DOI: 10.1111/1467-9566.12508.

12. Ishii M, Okuyama K (2017). Characteristics associated with freezing of gait in actual daily living in Parkinson's disease. J Phys Ther Sci 29(12): 2151-2156. DOI: 10.1589/jpts.29.2151.

13. Jacobs H, Heberlein I, Vieregge A, Vieregge P (2001). Personality traits in young patients with Parkinson's disease. Acta Neurol Scand 103(2): 82-87. DOI: 10.1034/j.16000404.2001.103002082.x.

14. Kang MY, Ellis-Hill C (2015). How do people live life successfully with Parkinson's disease? J Clin Nurs 24(15-16): 2314-2322. DOI: $10.1111 /$ jocn.12819.

15. Kalia LV, Lang E (2015). Parkinson's disease. Lancet 386(9996): 896-912. DOI: 10.1016/S0140-6736(14)61393-3.

16. Lin YP, Watson R, Tsai YF (2013). Dignity in care in the clinical setting: a narrative review. Nurs Ethics 20(2): 168-177. DOI: 10.1177/0969733012458609.

17. Maffoni M, Giardini A, Pierobon A, Ferrazzoli D, Frazzitta G (2017). Stigma experienced by Parkinson's disease patients: a descriptive review of qualitative studies. Parkinsons Dis 24 (1): 1-7. DOI: 10.1155/2017/7203259.

18. Matiti MR (2015). Learning to promote patient dignity: an inter-professional approach. Nurse Educ Pract 15(2): 108-110. DOI: 10.1016/j.nepr.2015.01.005

19. Nazzal MS, Khalil H (2017). Living with Parkinson's disease: a Jordanian perspective. Scand J Occup Ther 24(1): 74-82. DOI: $10.1080 / 11038128.2016 .1234643$.
20. Perepezko K, Hinkle JT, Shepard MD, Fischer N, Broen MPG, Leentjens AFG et al. (2019). Social role functioning in Parkinson's disease: a mixed-methods systematic review. Int J Geriatr Psychiatry 34(8): 1128-1138. DOI: 10.1002/gps.5137.

21. Pietkiewicz I, Smith JA (2014). A practical guide to using interpretative phenomenological analysis in qualitative research psychology. CPPJ 20(1): 7-14. DOI: 10.14691/CPPJ.20.1.7.

22. Shapira AL, Handzel R, Korczyn AD (2017). The lived experience of Parkinson's disease: A content analysis of Parkinson's patients' blogs. IMAJ 19(11): 685-690.

23. Sheehy TL, McDonough MH, Zauber S (2017). Social comparisons, social support, and self-perceptions in-group exercise for people with Parkinson's disease. J Appl Sport Psychol 29 (3): 285-303. DOI: $10.1080 / 10413200.2016 .1266711$.

24. Simpson J, McMillan H, Reeve D (2013). Reformulating psychological difficulties in people with Parkinson's disease: the potential of a social relational approach to disablism. Parkinsons Dis 2013: 608562. DOI: 10.1155/2013/608562.

25. Smith JA, Osborn M (2015) Interpretative phenomenological analysis as a useful methodology for research on the lived experience of pain. Br J Pain 9(1): 41-42. DOI: $10.1177 / 2049463714541642$.

26. Smith JA, Flowers P, Larkin M (2009). Interpretative phenomenological analysis. Theory, method and research. London: SAGE, 225 p.

27. Smith LJ, Shaw RL (2017). Learning to live with Parkinson's disease in the family unit: an interpretative phenomenological analysis of well-being. Med Health Care Philos 20: 13-21. DOI: 10.1007/s11019-016-9716-3.

28. Soleimani MA, Negarandeh R, Bastani F, Greysen R (2014) Disrupted social connectedness in people with Parkinson's disease. Br J Community Nurs 19(3): 136-141. DOI: 10.12968/ bjcn.2014.19.3.136.

29. Soundy A, Stubbs B, Roskel C (2014). The experience of Parkinson's disease: a systematic review and meta-ethnography. Sci World J 2014: 613592. DOI: 10.1155/2014/613592.

30. Stocchi F, Martínez-Martin P, Reichmann H (2014). Quality of life in Parkinson's disease - patient, clinical and research perspectives. Eur Neurol Rev 9(1): 12-18. DOI: 10.17925/ ENR.2014.09.01.12.

31. Tod AM, Kennedy F, Stocks AJ, McDonnell A, Ramaswamy B, Wood B, et al. (2016). Good-quality social care for people with Parkinson's disease: a qualitative study. BMJ Open 6(2): e006813. DOI: 10.1136/bmjopen-2014-006813.

32. Tranvåg O, Synnes O, McSherry W (2016). Stories of dignity within healthcare. Research, narratives and theories. Keswick: M\&K Publishing, $370 \mathrm{p}$.

33. Tsiouris KM, Gatsios D, Rigas G, Miljkovic D, Seljak BK, Bohanec M, et al. (2017). PD_Manager: an mHealth platform for Parkinson's disease patient management. Health Technol Lett 4(3): 102-108. DOI: 10.1049/htl.2017.0007.

34. Valcarenghi RV, Alvarez AM, Santos SSC, Siewert JS, Nunes SFL, Tomasi AVR (2018). The daily lives of people with Parkinson's disease. Rev Bras Enferm 71(2): 272-279. DOI: 10.1590/00347167-2016-0577.

35. van Gennip IE, Pasman HRW, Oosterveld-Vlug MG, Willems DL, Onwuteaka-Philipsen BD (2013). The development of a model of dignity in illness based on qualitative interviews with seriously ill patients. Int J Nurs Stud 50(8): 1080-1089. DOI: 10.1016/j.ijnurstu.2012.12.014.

36. van Gennip IE, Pasman HRW, Oosterveld-Vlug MG, Willems DL Onwuteaka-Philipsen BD (2015). Dynamics in the sense of dignity over the course of illness: a longitudinal study into the perspective of serious ill patients. Int J Nurs Stud 52(11): 1694-1704. DOI: 10.1016/j.ijnurstu.2015.06.010.

37. Vescovelli F, Sarti D, Ruini C (2018). Subjective and psychological well-being in Parkinson's disease: a systematic review. Acta Neurol Scand 138(1): 12-23. DOI: 10.1111/ane.12946.

38. Žiaková K, Čáp J, Miertová M, Gurková E, Kurucová R (2020). An interpretative phenomenological analysis of dignity in people with multiple sclerosis. Nurs Ethics 27(3): 686-700. DOI: 10.1177/0969733019897766. 